\title{
SUSTAINABILITY AND BANKING RISKS
}

\section{DOI: 10.17261/Pressacademia.2021.1512 \\ PAP- V.14-2021(38)-p.141-142}

\section{Hicabi Ersoy ${ }^{1}$, Canan Musluoglu ${ }^{2}$}

${ }^{1}$ Istanbul Commerce University, Finance Institute, Department of Banking, Istanbul, Turkey. hersoy@ticaret.edu.tr, 0000-0002-3573-1976

${ }^{2}$ Istanbul Commerce University, Finance Institute, Department of Banking, Istanbul, Turkey. canan.musluoglu@hotmail.com, 0000-0001-9890-4443

To cite this document

Ersoy, H., Musluoglu M., (2021). Sustainability and banking risks. PressAcademia Procedia (PAP), 14, 141-142.

Permanent link to this document: http://doi.org/10.17261/Pressacademia.2021.1512

Copyright: Published by PressAcademia and limited licensed re-use rights only.

\section{ABSTRACT}

Purpose - Environment, economy and finance are closely interrelated. While droughts, storms and forest fires pose a direct threat to physical assets, indirect risks arise due to policy changes brought about by the impact of national public and/or international agreements. These are called can be explained as transition risks. Similarly, orientation to renewable energy sources are also in the scope of transition risks. Because alternative energy sources production sectors and related sub-industries are adversely affected. These are the losses incurred in transitioning to a less polluting green economy. The more important the negative effects of the implementation of the Paris Agreement for the relevant economies, the greater the damage to be caused by non-implementation. The dilemma arises as to how fast the transition to a greener economy will take place and how its negative effects will affect the sectors and the financial system. Since the resources of the countries are insufficient to meet the losses, the main subject should be working on the financial risks bank are and will be exposed to.

Methodology- Examining the effects of traditional financial risk groups \& measuring risks should be the main methodology.

Findings - The common feature of all of the green economy factors is that they are customers of the financial sector, namely the banks that provide the allocation of resources in the economy. The potential effects of climate risk derives can be summarized below. in terms of credit risk, market risk, liquidity risk,operational risk \& reputation risk point of view. In terms of credit risk; the solvency of borrowers may weaken. In terms of market risk; the values of financial assets may decrease; asset prices may fluctuate. In terms of liquidity risk; there may be problems such as decrease in the resources of the banks; withdrawal of deposits. If we look in terms of operational risks; problems such as non- compliance with legal regulations, fraud may increase. Finally, if we look in terms of reputation risk; problems such as deterioration of market conditions and customer habits, non payment of checks may occur.

Conclusion - To predict the results that may arise because of environmental factors in the banking sector: It is necessary to work on credit risk in the scope of company, product and sector. In terms of market risks, it is necessary to examine the liquidity and price relationship of bank assets. As for operational risks, due to the limited information that banks share with the public, studies can be conducted on a case-bycase basis. Since the resources of the countries are insufficient to meet the losses, the above mentioned subjects are important to be worked on for financial risks bank are exposed to.

Keywords: Sustainability, banking, risk, environment, economy, finance.

JEL Codes: Q56,G24

\section{REFERENCES}

Kern, A., (2014). Stability and sustainability in banking reform: are environmental risks missing in Basel III? University Of Zurich Main Library, 27. https://www.zora.uzh.ch/id/eprint/103844/1/Alexander Basel Report Sept 2014.pdf.

Rockström, J.\& Sukhdev, P. (2016). Azote Images . Stockholm Resilience Centre., Stockholm University. https://www.stockholmresilience.org/download/18.2561f5bf15a1a341a523695/1488272270868/SRCs\%202016\%20Swedish\%202030\%2 OAgenda\%20HLPF\%20report\%20Final.pdf .

Bank For International Settlements, (2021). Climate-related risk drivers and their transmission channels. Basel Comitee on Banking Supervision. 4. https://www.bis.org/bcbs/publ/d517.pdf .

Türkiye Bankalar Birliği, (2021). Sürdürülebilir Finans Sunumu, Strateji Geliştirme Daire Başkanlığı. 9-12. https://www.tbb.org.tr/Content/Upload/Dokuman/7778/26.05.2021 FSK BDDK Surdurulebilirlik Sunumu.pdf 
Autorité de Contrôle Prudentiel et de Resolution, (2019). Climate change: which risks for banks and insurers? ACPR. 4-5.

https://acpr.banque-france.fr/sites/default/files/medias/documents/as_cover_note_en.pdf.

United Nations, (2020). Sustainable Development Goals. Sustainable Development Report.United Nations Department of Economic and Social Affairs. https://unstats.un.org/sdgs/report/2021/.

Bank For International Settlements, (2021). Climate-related risk drivers and their transmission channels. Basel Comitee on Banking Supervision, 1-20. https://www.bis.org/bcbs/publ/d517.pdf.

Weber, O. and Feltmate, B., (2016). Sustainable Banking, University of Toronto Press. https://www.degruyter.com/document/doi/10.3138/9781442629325-008/html

Weber, O., Dordi, T. \& Saravade, V. (2019). Strategies for Integrating the Canadian Financial Sector into Financing the Transition to a Lowcarbon Economy, 12-13. https://www.cigionline.org/sites/default/files/documents/Paper\%20no.217 0.pdf

Roy, M.K., Sarker, A.S. \& Parvez, S. (2015). Sustainability in banking industry: which way to move? ASA University Review, 9(2), 59-65. http://www.asaub.edu.bd/asaubreview/data/v9n2sl4.pdf 